\title{
Franco-British Relations and Rivalries: One- upmanship, Schadenfreude and the Weight of History
}

Les rivalités franco-britanniques : surenchères, jubilation et le poids de l'histoire

Richard Davis

\section{OpenEdition}

\section{Journals}

Electronic version

URL: https://journals.openedition.org/rfcb/8659

ISSN: 2429-4373

Publisher

CRECIB - Centre de recherche et d'études en civilisation britannique

\section{Electronic reference}

Richard Davis, "Franco-British Relations and Rivalries: One-upmanship, Schadenfreude and the Weight of History", Revue Française de Civilisation Britannique [Online], XXVII-1 | 2022, Online since 04 January 2022, connection on 01 February 2022. URL: http://journals.openedition.org/rfcb/8659

This text was automatically generated on 1 February 2022

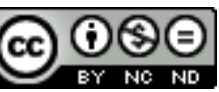

Revue française de civilisation britannique est mis à disposition selon les termes de la licence Creative Commons Attribution - Pas d'Utilisation Commerciale - Pas de Modification 4.0 International. 


\title{
Franco-British Relations and Rivalries: One-upmanship, Schadenfreude and the Weight of History
}

Les rivalités franco-britanniques : surenchères, jubilation et le poids de l'histoire

\author{
Richard Davis
}

\section{Introduction}

1 The most frequent presentation of Franco-British relations is one that combines, or juxtaposes, its positive and negative sides. A brief look through the numerous publications and articles that have attempted to address this question gives an indication of the paradoxes that are frequently resorted to when seeking to characterise the Franco-British relationship. The "entente" is variously "infernal" ${ }^{1}$ or "ice-cold" , forming an "impossible couple" or an "impossible alliance" 3 between the "best of enemies". At the same time, and despite the inherent difficulties, it remains an unavoidable relationship, an "impossible (yet), indispensable alliance". ${ }^{5}$

2 In the media, particularly the popular press, and among the general public the idea that the two countries are traditional enemies, unable either to understand each other or to work effectively together, that they are always ready to pick a fight even on relatively minor issues, has always been widely held. The academic literature has been no less inclined to focus on the more conflictual aspects of the Franco-British relationship than on its harmonious ones. No doubt there is more to be said about, more of interest in, conflict and rivalry than in harmony and cooperation. However, while there is less said about the positive side of the Franco-British relationship this should not lead us to conclude that this is aspect of the relationship is entirely absent. 
3 This paper focuses on some of this relationship's fundamental, and long-term, characteristics - rivalry, one-upmanship and schadenfreude - and will try to understand how they have been weighed down by the two countries' respective national histories and by the history of the Franco-British relationship itself. Or perhaps more accurately by the ways in which these histories have been interpreted. Memories of past events in the Franco-British relationship, taking into account both the personal memories and readings of history of some of the key decision-makers and the collective memories of the two countries, have formed the background to, and set the scene for, ensuing events and have played an important role in determining the outcomes at certain pivotal moments. The weight of history and the various 'realms of memory' have, in numerous ways, played an important role in the relationship between Britain and France over the course of the past 100 years.

\section{Realms of memory: The imaginary in Franco-British relations and rivalries}

4 All international relationships have a past, a history, the memory of which acts to condition how that relationship is conducted and how it evolves. Such histories and memories draw on and serve to construct how we see, or imagine, others, ourselves and our international relations. Nowhere has this been truer than in the Franco-British relationship. As Philip Bell underlined "France and Britain entered the twentieth century bearing a heavy burden from the past... Much of this mental baggage... had been carried from as long ago as the Hundred Years' War". ${ }^{6}$ The list of confrontations between the two countries, remembered long after, add up to a significant amount of 'mental baggage'. Numerous national heroes (and anti-heroes), memorable dates and places, come from this tumultuous Franco-British history, acting as a constant reminder of their past differences.

For Britain and France there has been no better 'other' than their neighbour across the Channel; no 'other' more present in their collective memories. The Anglo-French relationship has therefore served both as a lens through which they have looked at each other and as a mirror in which they have seen themselves. In the same way as memories can misrepresent the past, as they can be selective and used - or misused for present-day objectives, these Franco-British lenses and mirrors can also distort the images the two countries have of each other and of themselves. This often aggravates a relationship already marked by often acute susceptibility, misunderstanding, mistrust and a lack of mutual empathy. When combined, when we put these memories up to our mirrors, the picture becomes even more confused, even more prone to distortion. The mutually reinforcing interaction between, on the one hand, the ways in which FrancoBritish relations are conducted by both sides and, on the other, the ways in which collective representations are constructed or imagined means that memories can be both a constraint on British and French foreign policy makers and an instrument used to pursue their objectives.

6 The Franco-British 'couple' has a long history. Indeed, for some historians the very identities of Britain and France were created in opposition to each other. In some ways, therefore, the idea of Franco-British difference can be taken back to the very beginning of their national histories, seen as part of their respective DNAs. Over the centuries numerous collective representations became well established. Many of them are still 
with us. The belief that the two nations are fundamentally different - temperamentally, in their social, economic, cultural and political heritages, their different legal, ideological and philosophical traditions, in their business models - have all been used to underline the divergent ways in which the two countries see the world. Margaret Thatcher was picking up on a long-held belief when she contrasted France's traditions of Colbert with those of Adam Smith. Harold Wilson even identified a "theological difference" between the French-dominated EEC and the British preferred EFTA models. When Margaret Thatcher questioned France's true democratic credentials and its claims to be the home of liberty, especially when compared to Britain and the USA, she was expressing a widely-held view in Britain that sees France as veering between political instability and a quasi-autocracy. This vision of France was already widespread in the nineteenth century through such writers as Macaulay who delighted in drawing the comparison between the volatility and violence of French politics and people and the more fortunate British with their sense of progressive reform. Taken altogether some analysts have concluded that all this has meant that the two countries have been on separate, even divergent, historic paths for several centuries and that they have always existed in two different mental universes.

7 Beyond this sense of Franco-British difference, perhaps part of a wider difference between Britain and the Continent, there has been another widely-accepted view that Britain and France have always been, almost by nature, rivals and that they will inevitably remain so in the future. When in 1921 Clemenceau told Lloyd George that "Within an hour after the Armistice I had the impression that you had become once again the enemies of France", the latter replied, "has that not always been the traditional policy of my country?" 8 Was this a simple quip or a more deeply-based vision of Britain's relationship with France? Either way, it has been frequently quoted since 1921. Similarly, in 1964 de Gaulle argued that France's "greatest hereditary enemy was not Germany, it was England. From the Hundred Years War to Fashoda, she hardly ceased to struggle against us... True, she was our ally during two world wars, but she is not naturally inclined to wish us well." ${ }^{\prime \prime}$ Such memories remain firm fixtures in both countries. When, in 1963, Paul Reynaud complained to de Gaulle of the way he had thrown out the British application to enter the Common Market, reminding him of the debt France owed to Britain for its support during the War, in return he received a note, unsigned but in the unmistakable handwriting of the General, on which he had written "If away, forward to Waterloo, Belgium".${ }^{10}$ Whether or not this was true it was certainly reported as such by the British Embassy in Paris.

8 Such references to the two countries' past disagreements and their mutual mistrust come all too easily to both nations. No matter how frequent this portrayal has been made it should not, however, be taken as the complete picture of the Franco-British relationship. As much as the two countries have adopted different ideas and approaches they have also been connected by their numerous exchanges. At various times they have followed the other's example, adopted and copied their approaches, shared fundamental values, fought common causes, borrowed each other's language, food, music.... Much of this more positive portrayal of Franco-British relations has all too often been obscured by the negative side.

9 De Gaulle's view of Britain as the hereditary enemy of France is often quoted. His efforts to reach a reconciliation with Germany are equally well-known. At other times, however, notably during the Second World War, he presented a quite different picture: 
one of a tradition of Franco-British cooperation and of deep-rooted Franco-German conflict. Like other leaders, de Gaulle, whatever his "certaine idée de la France", was able to adapt his representation of Franco-British relations to suit his needs, according to the moment and to the person he was addressing. For example, at the same time as he was very publicly promoting the Franco-German rapprochement he was also telling the British in private discussions that he remained very suspicious of his new German partner and that, naturally, he still had more faith in the British. This conversation is hardly, if ever, recorded in the accounts of those events. Nonetheless, while the general knowledge and understanding of our respective pasts is diminishing, if we remember any history of Franco-British relations at all it is that of the past clashes. 1066 remains one of the few historic dates widely recognised in Britain. Waterloo and Trafalgar, Wellington and Nelson, Joan of Arc, Louis XIV and Napoleon, and what they represent, are still familiar. Whenever the two countries come up against each other, on the sports field, when their fishermen clash (off Newfoundland at the beginning of the 20th century or more recently off the Normandy coast), or when they are confronted by the mad cow disease, both sides still frequently resort to the vocabulary of warfare. These are not simple disagreements but fish and beef 'wars'. Just as schools in the past did a great deal to promote their respective national histories, often inculcating deeply entrenched ideas of Franco-British hostility, so the media today, particularly the British tabloid press, delights in the use of caricatured images, with references to the long list of their past conflicts, thus serving to further reinforce them in the collective memories. Numerous politicians have shown a willingness to do the same.

\section{Memories and the weight of history in Franco-British relations}

10 Present-day Franco-British confrontations can easily be seen within the context of, and as a continuity with, their past conflicts, as revenge for what is regarded as a past sleight or for previous defeats at the hands of their age-old rival. This frequently follows on from a selective use of past events. We choose to remember and at times to commemorate, or we chose to ignore or forget, different episodes from the past, to achieve a certain objective or to defend an argument. We can equally choose, or attempt to choose, the history we leave as a legacy for future generations. All this is done to suit our mood and the needs of the moment, and we can change or alter our memories as circumstances change over time. In the record of Franco-British relations these can be taken positively to remember collaborations and joint victories. Or previous enmity and confrontations. It has been said that the Entente between Britain and France should be defined as " $a$ climate and not an alliance". ${ }^{11}$ If this is the case, then the climate has been very changeable. In this respect, and given the trauma that these involved, it is the memories of the two world wars that stand out most.

11 It has been argued that the Anglo-American 'special relationship' "waxed fat on war". ${ }^{12}$ But what of the Franco-British relationship? In terms of collective memory and lessons drawn, the differences are significant. Although Britain and France spent longer fighting as allies in the two world wars than did Britain and the USA the legacies that these experiences left were quite different. Despite their experience as wartime allies, Britain and France never entirely shook off their image of traditional enemies or rivals. 

was fought largely on French soil and was thus regarded by the French as a war to liberate their homeland. Their final losses at 1.4 million dead were significantly greater than those of Britain. Equally, the conduct of the War did little to establish a sense of common cause with a tendency for each country to focus on its own sector and to emphasise the extent of its contribution to the overall war effort. British and French troops fighting on the front seem to have had little awareness of their allies. For many in France, both during the War and later, there was a feeling that the British had in fact done relatively little and that they had not always been reliable allies. Despite the obvious sacrifices made by France the British too could sometimes downplay the French role, particularly in other theatres of war such as the Middle East. Nor did the personal experiences of those who had fought in the war do much to establish any sense of Franco-British understanding or solidarity. De Gaulle was far from alone in complaining at the end of the War that the British had not pulled their weight during the course of the previous four years of conflict. Churchill's far more positive view of the French army, a view that he held steadfastly throughout the inter-war years up until the events of 1940, was not generally accepted in Britain. For most British exservicemen the overwhelming sentiment was one of revulsion at the horrors of the War. Some of them placed the blame on the French for having dragged them into the conflict. This was accompanied by widespread feelings of sympathy with Germany, something that was largely absent in France. A significant part of British opinion, including John Maynard Keynes and Ramsay MacDonald, condemned what they saw as French intransigence towards Germany. These contrasting memories of war, and the lessons that were taken from them, fed into starkly divergent foreign policy approaches in Britain and France for the most part of the 1920s and 1930s. became the most evocative of the "lieux de mémoire". Remembrance days, war memorials and the representations of the War in film, literature and other forms became deeply rooted in both countries' collective memories. They remain so today more than a century later. These, however, have always been for the most part national memories. Indeed, in some ways they have played down the part played by others. Studies of French school books being used in the 1960s, for example, show how little the British role in the First World War was recognised. In Britain it is the Somme rather than Verdun that is most remembered. The French contribution to both battles is largely ignored in British accounts as is the French role in the Gallipoli campaign. French troops outnumbered those of New Zealand and Australia yet it is essentially as an ANZAC battle that this is remembered today.

If the memories of 1914-18 left a deep mark on the following decades and played a key role in determining Franco-British relations, then the same is no less the case for the experiences of the Second World War. Indeed, the memories of this conflict had perhaps an even greater impact on the evolution of Franco-British relations in the following years. There are of course obvious differences in the experiences of the Second World War compared to the First, for both Britain and for France and for Franco-British relations. The memories of those experiences are, therefore, also quite different. From the outset of War there were strains in the Franco-British relationship. For the French the British contribution in terms of military manpower was disproportionately small compared to the forces they were mobilising while British 
confidence in their ally's resolve was far from entire. The events of May-June 1940 revealed the full extent of the divisions between the two allies that had, up to that point, been kept beneath the surface. The gulf that emerged between them in those fateful weeks had still not healed several decades later.

Military defeat in 1940 inevitably led to a series of mutual recriminations. British accounts focused on the failure of the political and military leadership of France. This image of France as endemically weak, divided and indecisive, at times morally and politically corrupt, for some rotten to the core, left an almost indelible impression on the British especially when this was compared to the far more positive wartime record of the British, something that was played up in following accounts. The French in return complained of what they saw as the precipitous retreat of the British Army to the Channel ports and the British refusal to commit more of the RAF's resources to the battle in France. For France 1940 is remembered as the country's 'débâcle'; for Britain it was a lost battle, not a lost war. The rout of the British Army in France in May-June 1940 was somehow reinvented as the 'Dunkirk spirit', an epic act of heroism, an image that has remained an integral part of the British collective memory of the War. French portrayals of this evacuation are, understandably, quite different, often blaming the British for abandoning them to face the German onslaught alone. The British attack on the French fleet at Mers el-Kébir was quickly forgotten on the British side, overtaken by more immediate concerns with the onset of the Battle of Britain, just as Fashoda had been forty years previously. This was far from the case in France where it was emphasised by the Vichy authorities in their anti-British propaganda. This was accompanied by a call to form squadrons to fight the British named after Joan of Arc, Saint Helena, Fashoda, Mers-el-Kebir and Dakar. Throughout the War images of Joan of Arc's martyrdom at the hands of the English became a favourite theme of Vichy propaganda. In some ways Dunkirk and the wider 'débâcle' exemplify the differing Franco-British memories of the War as a whole leaving a deep scar on both countries, particularly France for whom the defeat was complete and undeniable. The ensuing collaboration of the Vichy regime served to deepen the scar. In contrast, Britain avoided the legacy of defeat, occupation and collaboration. In many ways these different wartime experiences and, equally importantly, the later records and memories of these events, set the two countries on diverging paths in what Philip Bell described as a 'parting of the ways'. This was to have lasting consequences for FrancoBritish relations.

16 This point was made several decades later by Harold Macmillan, himself an important player in the Franco-British relationship during the War. Looking back on de Gaulle's opposition to Britain's application to enter the EEC in the 1960s he remarked

The truth is, and I may be cynical but I fear it's true, if Hitler had danced in London we'd have had no trouble with de Gaulle. If we'd given in to Hitler we'd have had no trouble with de Gaulle. What he couldn't forgive us is that we held on and that we saved France. People can forgive an injury but they can hardly ever forgive a benefit. ${ }^{13}$

17 Many others in Britain held the same view that Britain had rescued de Gaulle in 1940 and had saved France thereafter. What is sometimes seen as a lack of French gratitude for the British sacrifices made in support of France during the War was still being referred to many years later. In general, there has been a resentment on the British side that their efforts during the Second World War have not been fully recognised in France. British pride can easily be hurt whenever commemorations of the War give 
pride of place to the Americans while playing down their role. In 1964 de Gaulle refused to attend the commemorations of D-Day in Normandy although he did attend those for the landings in Provence. French school books in the 1960s paid little attention to Britain during the War. In return the British have never been inclined to attribute anything more than a secondary role to the French in the overall allied war effort. Instead it is rather their defeat that came to be emphasised while the role of the Free French forces and the resistance were seen as heroic but largely insignificant in the broader picture. Indeed, if the Free French or the French Resistance were able to play a role at all it was thanks to the support they received from Britain. De Gaulle's personal role is also seen as mixed: as much as a burden and an obstacle as an effective support. Above all, British accounts of de Gaulle's wartime role emphasise the idea that he was in some ways made by the British, taken out of France in June 1940 as France collapsed and given refuge in London. For Robert Tombs de Gaulle was "a pernicious nuisance... What did de (he) actually do, apart from fostering a myth that subsequently gave much satisfaction to nationalists?" while his "sullen and paranoid intransigence" 14 did little to contribute to the war effort. Other British accounts have emphasised de Gaulle's successful 'implanting (of) the myth of self-liberation' 15 and have gone so far as to argue that "modern France is built on (this) lie". ${ }^{16}$

The French historical perspective of the War is quite different, especially with regard to the role played by de Gaulle. Gaullist memories of the War also focus on resentment at France's treatment at the hands of the British, and the Americans. Events in Syria and Madagascar, for example, where Anglo-American forces occupied these French colonies without any involvement of the Free French are prominent in Gaullist accounts. French public opinion as revealed in numerous polls and the various press accounts of this history up to the present day have by and large followed this Gaullist interpretation.

The legacy of these past events was played out in an obvious and important fashion during the years of the de Gaulle presidency when the British government was attempting to enter the EEC. This episode of Anglo-French relations clearly shows the ways in which memories of the past became firmly entrenched in later narratives which in turn had a direct influence over consequent Franco-British relations. De Gaulle, who had been forced to play second fiddle during the wartime years to the big three of Roosevelt, Stalin and Churchill, was by the late 1950s at the head of a resurgent France unlike Britain whose fortunes were visibly in decline. There is little doubt that his feelings, a mix of hurt personal and national pride built up during his often difficult wartime relations with his allies, now played an important role in his attitudes to the British.

Amongst the numerous head-to-head meetings during the War between Churchill and de Gaulle the one that stands out, and the one that has been most frequently remembered in later accounts, took place on the eve of the Normandy landings. De Gaulle's memoirs, written and published shortly after the War, emphasise the stormy nature of this meeting with Churchill violently expressing his priority for the alliance with the USA over that with France, famously saying that he would always choose Roosevelt over de Gaulle and the 'high seas' over Europe. De Gaulle returned to this same meeting on several occasions in the 1960s in his meetings with the British and his ministers. Churchill's account downplays both the importance and the violence of these exchanges with de Gaulle but it is the Gaullist account has been reproduced in almost every subsequent account and which has become entrenched in the record of wartime 
Franco-British relations. This, however, was just one meeting among many. On other occasions their exchanges were far more harmonious. Nor was Churchill the only voice of the British government. Indeed, the Foreign Secretary, Anthony Eden, and Ernest Bevin, the Minister of Labour, went out of their way to say precisely this to de Gaulle after he left the meeting. Such reassurances, however, seemed to have had little impact on de Gaulle or on the memories he kept. By the 1960s he had clearly not put his past disagreements with his wartime British allies behind him. Nor had he abandoned his vision, deep-rooted in his childhood and his education, of a Franco-British relationship rooted in a centuries-old confrontation.

These conflicting memories and the different uses to which they were put were key elements in the crisis of Franco-British relations that lasted throughout the 1960s as de Gaulle obstructed Britain's attempts to enter the Common Market. Macmillan's hopes that the memories of their wartime collaboration, when he was the British envoy to de Gaulle in North Africa, would play out in his favour were dashed by de Gaulle's veto in 1963. For the British, there was no doubt that the behaviour of the French President could be explained by his historically-based, and in their view out-dated, attitude. Macmillan complained that de Gaulle was attempting to re-impose Napoleon's Continental blockade on Britain. The Foreign Office and the British Embassy in Paris wrote numerous reports portraying de Gaulle in the guise of Joan of Arc, Louis XIV or Napoleon. Cartoonists in British newspapers took a similar approach producing some memorable images of de Gaulle in these various roles, adding those of Charlemagne, Julius Caesar, the Kaiser and even Hitler. Another favourite was to present de Gaulle as a somewhat deranged Joan of Arc listening to mysterious voices or as an imperious Louis XIV or Napoleon resisting British advances. As de Gaulle was obviously coming out on top in this latest Franco-British confrontation the historical roles could often be reversed with the unfortunate British Prime Ministers, Harold Macmillan and Harold Wilson, playing the parts of Napoleon meeting his Waterloo or of Joan of Arc at the stake. Just as the Franco-British exchanges over Europe in the 1960s were conducted with an almost constant look back over their shoulders to their previous conflicts so, in the same way, this particular episode left its own legacy for future Franco-British relations. For the British in particular these troubled years in their relations with France were to leave very bitter memories of what they regarded as de Gaulle's duplicity.

\section{A shifting balance: one-upmanship and schadenfreude}

Underlying the repeated British diplomatic defeats at the hands of the French in the 1960s over the question of their membership of the EEC was the changing balance of power between the two countries. Franco-British relations therefore also need also to be seen in the context of the two countries' relative strengths and weaknesses as the shifting balance between them has often been decisive in determining how these relations have been played out. This in turn leads to the questions of one-upmanship and schadenfreude which have often characterised this Franco-British relationship; how, at various times, the two countries have looked down on each other, how they have often tended to see in each other a suitable scapegoat in what Dominique de Villepin called at the height of the Iraq crisis in 2003 the 'blame game'. 

broadest sense this has always been the case. Neither has truly dominated the other as, for example, the USA today has an imbalanced relationship with all its allies. In terms of population and the economy, in the fields of science, philosophy or on the sports field, or whatever other area we consider, the two countries have never been far apart. That is not to say that there have not been ups and downs in this relationship or that the balance has not swung backwards and forwards. In fact, the two countries, as partners and rivals, allies and competitors, have rarely stopped looking at each another, sometimes looking down on their neighbour, sometimes pitying them, crowing about their own success and victories or bemoaning their failures and resenting defeats at the other's hands.

British forced to go cap in hand to ask the French to support sterling. By the 1930s, however, it was the weakness and insecurity of France that was foremost in British thinking about the Franco-British relationship. The radically different experiences of the Second World War widened the gulf between the two countries. Britain held onto its role, or at least its image, as one of the 'big three' while de Gaulle was humiliatingly excluded from the international high table. These contrasting experiences were to have a long-lasting impact on both sides. After the War, the failure of the Fourth French Republic to resolve the country's chronic problems of political instability continued to compare unfavourably with Britain's apparently more solid political regime. By the end of the 1950s and into the 60s and 70s, however, the rapid recovery of the French economy, and the relative economic stagnation of Britain, produced a significant shift in the Franco-British balance. The establishment of the Fifth Republic in 1958 and de Gaulle's forceful policy of reviving French national prestige, however superficial this may have been, had a major impact. Since then the two countries have settled down into broadly similar patterns although whenever one side appears to be moving ahead of the other, in whatever indicator we choose to take, then we can be sure that this will be remarked upon in the on-going battle to keep up with and, if possible out do, the other.

The mutual recriminations between Britain and France have formed another characteristic part of their relationship, whether they saw themselves as being the dominant or the inferior partner. Britain, for example, could just as easily complain about French military strength in the 1920s and early 1930s, to the point of sometimes seeing France as the principal threat to their own security, and, only a few years later, criticise it for its military weaknesses. Many in France complained in the 1930s that they were unable to break free from their 'English governess' leading them towards the appeasement of Germany although this was in many ways an attempt to use the British as a scapegoat for their own weaknesses and indecision. The collapse of France in 1940 confirmed the British view of France as fundamentally weak in all sorts of ways and unleashed a wave of complaints and disparagement of their erstwhile allies. Such views lingered on well after the end of the War and France in the 1950s was still seen by many in Britain as hopelessly behind the times, held back by its inherent weaknesses and its national character. As late as 1963 the British Ambassador, Pierson Dixon, was still able to identify what he regarded as the "naturally critical and destructive bent of Gaul". ${ }^{17}$ Even while de Gaulle was imposing his humiliating veto on the British application to enter the EEC Dixon was still able to see dismiss him as a leader comparable to the very

Revue Française de Civilisation Britannique, XXVII-1 | 2022 
unimpressive and insubstantial Napoleon III, play-acting a similarly unconvincing part on the world stage.

Underlying all these comparisons, flattering for one side and derogatory for the other, is the fundamental sense of rivalry between the two nations. One recent British Ambassador to France has argued that the "intermingled history" of Britain and France has been marked by "a sense of rivalry, a readiness to criticize, a reciprocity of schadenfreude where the British and French press leap at opportunities to report the troubles of the other country". ${ }^{18}$ Douglas Hurd has similarly written that

There will always be an element of tease and rivalry in the relationship between France and Britain. To take mild pleasure in each other's small setbacks... is part of the give and take of life in our two countries. It is born of our history... From time to time this friendly competition and rivalry degenerates into real irritation and bad-tempered tension. ${ }^{19}$

Hurd is right to argue that this does not detract from the fundamental community of interest between the two nations or from the need for them to work together. Yet the flow of such teasing, and the frequency with which it does spill over into bad-tempered tension, deliberately sought by some, has sometimes reached levels where it has done damage to the effective working of the Franco-British relationship.

The schadenfreude mentioned by Hurd, perhaps based on the belief, or the hope, that by putting the other down their own country will appear in a more favourable light, is evident in many of de Gaulle's views of the British. He certainly took a certain delight in looking down on what, by the 1960s, he regarded as his unfortunate neighbours. The "poor English", he said, were "in complete disarray", "broken-down"20, "lurching" and "tottering"; sterling was "on its last legs, the English too", while Britain "doesn't count for much any longer". As for Britain's leaders they were "nouilles" and Harold Wilson a "crank". ${ }^{21}$ But perhaps the greatest expression of French disdain for their British neighbour has been to ignore them on the international scene. Already in the 1960s de Gaulle had dismissed the British as the very junior partners of their American masters, as an increasingly irrelevant part of the 'Anglo-Saxon' bloc. In 1995 François Crouzet identified the same tendency arguing that Britain "no longer counts for much in the (French) national consciousness : it isn't hated... rather simply ignored; it isn't a model, it is of no interest." 22 Jacques Attali made the same point. England, he said, "is something which is not a standard for anything... it is not an enemy, it's not a best ally, it's not a criteria of anything." ${ }^{23}$

The British have been no less inclined to take a similar dismissive approach towards the French whenever possible. British Whigs, Conservatives and economic liberals from Macaulay to Margaret Thatcher have frequently criticised France. The apparently more pro-French Tony Blair was also prone to similar remarks describing Britain in 2005 as a country "that increasingly sets the standard" compared to "the malaise of France." Others have adopted a more aggressively and insulting tone often using the type of pejorative references to France's wartime record seen above. At the time of the 2003 Iraq War parts of the tabloid press latched onto the description of the French as "cheese eating surrender monkeys." 


\section{Conclusion} lost much of their importance. Looking back over previous centuries, it may be possible to see "How 300 Years of Anglo-French Rivalry Shaped the World". ${ }^{24}$ Any such claim for the current situation would be absurd, either at a regional, European, level or a global one. A more viable case could, however, be made for their relations during the first half of the twentieth century. Since then, as the world entered and then left the era of the Cold War, as decolonisation removed the greater part of both countries' global roles, and as their relative economic and military strengths waned, their importance in world affairs has been in constant decline. Yet while their relations have lost much of their earlier significance their rivalry, quarrels and clashes have retained much of their previous acrimony. Their disagreements may be little more than petty arguments taking place away from the more important centres of decision-making at the European and global levels but old habits die hard and the traditions of Franco-British diplomatic rivalry and antagonism are still easily reignited.

31 The default position for many British governments when faced with a variety of difficulties has been to blame the French, using 'frog bashing' as a means of avoiding responsibilities and winning over a part of public opinion that is always only too willing to see the French as the source of Britain's problems and failings. This was notably the case in 2003 when Tony Blair blatantly sought, and in part succeeded, in surviving the crisis engendered by his support for the War in Iraq by condemning the French President, Jacques Chirac, for his failure to stand by his allies.

Today, as the UK is on the point of leaving the EU, we may wonder whether FrancoBritish relations still matter. After all, what do the two countries have left to quarrel about? Their colonies are long gone; at a time when London is asking for an EU divorce can Britain now contest the leadership of Europe as it did throughout the sixties and during the Blair years? As the USA likewise retreats into itself do we need to argue over who is that country's oldest or most dependable ally? Have anti-French feelings in Britain been subsumed into a more general Europhobia and has France really lost interest in Britain?

Whatever the outcome of the Brexit crisis we can expect some in Britain to adopt a similar 'blame-game' strategy as the one that targeted France in 2003 with responsibility for the lack of progress in reaching a UK-EU divorce settlement placed at the feet of the uncooperative, intransigent and, for some, vindicative French. Such arguments are being used to reinforce their argument that Britain outside the EU will be well rid of such foreign, especially French, connections. While very few in France are rejoicing there are some who find consolation in the fact that Brexit will do more damage to the UK than to the remaining $27 \mathrm{EU}$ members. For one French observer the British have shot themselves in the foot by voting to leave the EU. If the British have shot themselves in one foot, he went on, then the French should shoot them in the other one.

Recent events, and the likelihood that Britain will leave the EU, will surely further diminish the importance of the Franco-British relationship. Despite assurances from the government that Britain is leaving the EU but not leaving Europe, the Brexit project can hardly mean that Britain and France are coming closer. While Britain cannot cut itself off from Europe or from France their future relations will inevitably lose much of

Revue Française de Civilisation Britannique, XXVII-1 | 2022 
their wider significance post-Brexit. At the same time, the two sides have not quite put their past differences behind them and the potential for further clashes and arguments remains. Much of the Brexit debate in Britain continues to be backward-looking and references to the history of relations with the Continent, with France and Germany in particular, continue to frame much of the current debate. Franco-British rivalry still seems firmly entrenched in attitudes and past differences can reappear at short notice with each side ready to take up their previous positions and resume their ancestral struggle. Even if there is very little left to fight over. Alternatively, if it is true that "les gens heureux n'ont pas d'histoire" then perhaps Britain and France are settling into a peaceful, but more distanced, relationship that will no longer cause so much friction. This may lead to less being written about this previously passionate relationship. After all who wants to hear about a story where everything runs smoothly and everyone lives happily ever after? The best-selling book on the Franco-British relationship is probably Peter Clark's 'A Thousand Years of Annoying the French'. Would he have sold so many books with titles such as 'A thousand years of how Britain and France have got on'? Much of the conflict between Britain and France has become superficial. They remain linked in numerous ways, nearly all of them to their mutual advantage. François Bédarida wrote in 1994 on the occasion of the opening of the Channel tunnel that "rivalries between the two countries were the legacy of history and a part of national identity". Twenty-five years later, that legacy is drifting further into the past. Rivalries may occasionally flare up but they lack their previous passion. As for forming part of our national identities, the world has moved on and British and French identities are now open to far more important influences than that of the Franco-British relationship.

\section{BIBLIOGRAPHY}

PREM 11 Prime Minister's Office: Correspondence and Papers, 1951-1964, The National Archives, Kew.

“Entente Cordiale", BBC documentary, Radio 4, 1994.

Bell, Philip, France and Britain: Entente and Estrangement 1900-1940 (London, Longman, 1996).

Bell, Philip, France and Britain, 1940-1994. The Long Separation (London, Routledge, 1997).

Chassaigne, Philippe and Dockrill, Michael Anglo-French Relations 1898-1998. From Fashoda to Jospin

(London, Palgrave, 2002).

Cockerell, Michael, 2003 BBC documentary, "Affairs with the French".

Cooper-Richet, Diana and Rapoport, Michel (Eds.), L'Entente Cordiale. Cent ans de relations culturelles franco-britanniques (1904-2004) (Paris, Creaphis, 2006).

Crouzet, François, De la supériorité de l'Angleterre sur la France, l'économique et l'imaginaire, XVII ${ }^{e}-X X^{e}$ siècles (Paris, Perrin, 1985).

Danchev, Alex, On Specialness: Essays in Anglo-American relations (London, Macmillan, 1998). 
Gazeau, Véronique and Genet, Jean-Philippe, La France et les îles Britanniques un couple impossible? (Paris, CNRS, 2007).

Gibson, Robert, Best of Enemies (London, Impress, 2004).

Mayne, Richard, Cross-Channel Currents: 100 years of the Entente Cordiale (London, Routledge, 2004).

Mead, Walter Russell, "Entente Infernale: How 300 Years of Anglo-French Rivalry Shaped the World", Foreign Affairs, Vol. 86, No. 4 (Jul.-Aug. 2007), pp. 147-152. Review of That Sweet Enemy by Robert Tombs and Isabelle Tombs (London, Heinemann, 2006).

Peyrefitte, Alain, C'était de Gaulle. Tome 1. «La France redevient la France » (Paris, Editions de Fallois, Fayard, 1994).

Peyrefitte, Alain, C'était de Gaulle. Tome 2 : «La France reprend sa place dans le monde » (Paris, Editions de Fallois, Fayard, 1997).

Roudaut, Christian, L'Entente glaciale. Français - anglais : les raisons de le discorde (Paris, Alban, 2004). Sanderson, Claire, L'impossible alliance ? France, Grande-Bretagne, et défense de l'Europe (1945-1958) (Paris, Publications de la Sorbonne, 2003).

Tombs, Isabelle and Robert, That Sweet Enemy. The French and the British from the Sun King to the Present (London, Heinemann, 2006).

Watson, D. R., "The Making of the Treaty of Versailles", in Neville Waites (ed.), Troubled Neighbours (London, Littlehampton Book Services 1971).

Wilson, Harold, A Prime Minister on Prime Ministers (London, Weidenfeld and Nicolson, 1977).

\section{NOTES}

1. "Entente Infernale: How 300 Years of Anglo-French Rivalry Shaped the World", Walter Russell Mead, Foreign Affairs, Vol. 86, No. 4 (Jul.-Aug. 2007), pp. 147-152. Review of That Sweet Enemy by Robert Tombs, Isabelle Tombs (London, Heinemann, 2006).

2. Christian Roudaut, L'Entente glaciale. Français - anglais : les raisons de le discorde (Paris, Alban, 2004).

3. Véronique Gazeau and Jean-Philippe Genet, La France et les îles Britanniques un couple impossible? (Paris, CNRS, 2007) ; Claire Sanderson. L'impossible alliance? France, Grande-Bretagne, et défense de l'Europe (1945-1958) (Paris, Publications de la Sorbonne, 2003).

4. Robert Gibson, Best of Enemies (London, Impress, 2004).

5. The Economist, 1 December 2011.

6. Philip Bell, France and Britain: Entente and Estrangement 1900-1940 (London, Longman, 1996) p. 6, chapter 'The Remembrance of things past'.

7. Harold Wilson, A Prime Minister on Prime Ministers (London, Weidenfeld and Nicolson, 1977) p. 321.

8. D. R. Watson, 'The Making of the Treaty of Versailles', in Neville Waites (ed.), Troubled Neighbours (London, Littlehampton Book Services 1971) p. 67.

9. Tombs, Sweet Enemy, p. 605.

10. Despatch Dixon to Caccia 6 February 1964. Prime Minister's Office, PREM 11/4811, The National Archives, Kew.

11. Georges Bidault, 1954. Quoted in Diana Cooper-Richet and Michel Rapoport (Eds), L'Entente Cordiale. Cent ans de relations culturelles franco-britanniques (1904-2004) (Paris, Creaphis, 2006) p. 353.

12. Alex Danchev, On Specialness: Essays in Anglo-American relations (London, Macmillan, 1998). 
13. Michael Cockerell, 2003 BBC documentary, "Affairs with the French".

14. Tombs, Sweet Enemy, p. 598.

15. Philip Bell, France and Britain, 1940-1994. The Long Separation (London, Routledge, 1997) p. 287.

16. Sunday Telegraph, 27 February 1994.

17. Dixon to the Foreign Office, 3 January 1963.

18. Philippe Chassaigne and Michael Dockrill, Anglo-French Relations 1898-1998. From Fashoda to Jospin (London, Palgrave, 2002), p. 8.

19. Richard Mayne, Cross-Channel Currents: 100 years of the Entente Cordiale (London, Routledge, 2004) p. 288.

20. Alain Peyrefitte, C'était de Gaulle. Tome 1. "La France redevient la France " (Paris, Editions de Fallois, Fayard, 1994), p. 419, p. 375 and p. 335.

21. Alain Peyrefitte, C'était de Gaulle. Tome 2: «La France reprend sa place dans le monde» (Paris, Editions de Fallois, Fayard, 1997), p. 37 and p. 79, pp 308-309, p. 310.

22. François Crouzet, De la supériorité de l'Angleterre sur la France, l'économique et l'imaginaire, XVII ${ }^{e}$ $X X^{e}$ siècles (Paris, Perrin, 1985).

23. 'Entente Cordiale', BBC documentary, Radio 4, 1994.

24. Mead, Anglo-French Rivalry.

\section{ABSTRACTS}

The relations between Britain and France (taken here at the inter-state and governmental level for the most part) have consistently been unable to break free of previous conflicts and rivalries, however distant they may have been. Memories of these, even long after the event, have frequently been key points of reference and have served to weigh down on the diplomatic, as well as the popular, relations between the two countries. This is reinforced by their deep-rooted rivalry, often relating to the two countries' shared past, that has often blocked the efforts to work effectively together, no matter how deep their common interests. The concept of schadenfreude seems particularly relevant here to the record of Franco-British relations.

These questions are studied with particular reference to two broad periods allowing an analysis of the evolution of Franco-British relations in the light of these concepts. Firstly, the post-second world war period up to the end of the 1960s. These years were particularly difficult ones for Franco-British relations and also saw an important shift in the balance between the two countries. Against the background of European construction, and still very much in the wake of the events of the war which did so much (and which still do so much today) to influence how the two countries saw one another, both British and French leaders made constant references to the record, recent and more distant, of Franco-British relations. Secondly, the paper addresses the more recent ways in which references to past rivalries have continued to have a negative impact on Franco-British relations, up to and including the debate around Brexit.

Les relations entre la Grande-Bretagne et la France (prises ici aux niveaux inter-gouvernemental et interétatique) n'ont jamais réussi à se libérer des conflits et des rivalités du passé, même très anciens. Les souvenirs de ces événements, parfois des années plus tard, ont souvent servi de références. En conséquence le passé a souvent pesé lourdement sur les relations diplomatiques entre les deux pays. Il a joué également un rôle important dans la formation de l'opinion publique. Cet aspect des relations franco-britanniques est renforcé par le profond sentiment de 
rivalité entre les deux pays, qui fait souvent référence à leurs relations passées, et qui a parfois empêché leurs efforts de collaboration malgré les intérêts communs. Le concept de schadenfreude (le fait de se réjouir du malheur d'autrui) semble particulièrement approprié pour définir les relations franco-britanniques.

Toutes ces questions sont analysées ici à travers deux périodes clés dans les relations francobritanniques afin d'étudier son évolution dans le temps. D'abord, les années post-Deuxième Guerre mondiale jusqu'aux années 1960, une période de grandes tensions entre les deux pays et de rééquilibrage dans leurs positions et forces relatives. Sur fond de construction européenne, et toujours dans l'ombre de la Guerre qui a beaucoup pesé sur les images et les réputations des deux pays, les dirigeants britanniques et français ont constamment conduit leurs politiques étrangères en faisant référence à l'histoire des relations franco-britanniques. En conclusion, l'article analyse la période plus récente, y compris le débat autour du "Brexit ", et considère comment cette tendance à regarder vers le passé, en particulier l'histoire des rivalités franco-britanniques, a continué d'avoir un impact négatif sur leurs relations.

\section{INDEX}

Mots-clés: relations franco-britanniques, Entente, Brexit, de Gaulle

Keywords: Franco-British relations, Entente, Brexit, de Gaulle

\section{AUTHOR}

\section{RICHARD DAVIS}

CLIMAS, University of Bordeaux-Montaigne.

Richard Davis est Professeur à l'Université de Bordeaux-Montaigne où il enseigne la civilisation et l'histoire britanniques $\mathrm{du} \mathrm{XX}$ siècle. Il est diplômé de la LSE où il a obtenu une licence en sciences politiques et relations internationales et de l'Université de Sheffield ou il a soutenu une thèse sur les relations franco-britanniques dans les années 1930. Spécialiste de l'histoire contemporaine de la Grande-Bretagne et en particulier de ses relations avec les autres pays d'Europe, il est l'auteur de plusieurs ouvrages et d'articles sur la politique étrangère de la Grande-Bretagne depuis 1945, les relations avec la France et la question européenne en GrandeBretagne. 